15

\title{
Формирование литографических рисунков ограненными микрочастицами оксида цинка на кремниевой подложке
}

\author{
(C) А.А. Бобков ${ }^{1,2}$, И.А. Пронин ${ }^{1,2, \uparrow}$, В.А. Мошников ${ }^{1,2}$, \\ Н.Д. Якушова ${ }^{1}$, А.А. Карманов ${ }^{1}$, И.А. Аверин ${ }^{1}$, \\ П.А. Сомов ${ }^{2}$, Е.И. Теруков ${ }^{3}$ \\ ${ }^{1}$ Пензенский государственный университет, Пенза, Россия \\ ${ }^{2}$ Санкт-Петербургский государственный электротехнический университет \\ „ЛЭТИ“, Санкт-Петербург, Россия \\ ${ }^{3}$ Физико-технический институт им. А.Ф. Иоффре РАН, Санкт-Петербург, \\ Россия \\ ฯ E-mail: pronin_i90@mail.ru
}

Поступило в Редакцию 7 марта 2018 г.

В рамках гидротермального метода разработаны приемы литографии, совместимой с кремниевой технологией. При этом топологические рисунки формируются из ограненных микрокристаллов с развитой поверхностью. Особый интерес представляют перспективы реализации новых иерархических структур.

DOI: 10.21883/PJTF.2018.15.46445.17281

Фрактальные структуры и разработка методов их синтеза занимают важное место в современном материаловедении. За счет высоких значений удельной площади поверхности такие структуры имеют перспективы использования в сенсорике [1,2], катализе [3], альтернативной энергетике [4,5], биологии и медицине [6]. Особый интерес представляет разработка технологических приемов формирования локальных фрактальных структур на заданных участках поверхности, например, при разработке мультисенсорных систем распознавания газовых смесей с повышенными сенсорным откликом и селективностью, фрактальных $E N Z$-метаматериалов [7] для фотокатализаторов с широким спектром поглощения видимого излучения.

В [8] нами были рассмотрены приемы нанолитографической самосборки коллоидных наночастиц для развития фрактальной нанолитографии. В настоящей работе показана принципиальная возмож- 
ность формирования литографических рисунков, первичными элементами которых являются ограненные микрокристаллы. Этот новый тип иерархических структур расширяет функциональные возможности наноструктурированных материалов, так как монокристаллические нанообъекты обладают всеми свойствами, обусловленными симметрией кристалла, повышенными каталитическими, высокими газочувствительными свойствами и др. Одновременно эти структуры в зависимости от порядка расположения монокристаллических нанообъектов могут характеризоваться уникальными свойствами фрактальных структур или обеспечивать процессы перколяции за счет создания особых поверхностных фаз. Например, на иерархических структурах с базовыми нанокристаллитами $\mathrm{ZnO}$ создание контакта $\mathrm{ZnO} / \mathrm{SnO}_{2}$ перспективно для формирования сенсоров, чувствительных не только к угарному, но и к углекислому газу. Эффект чувствительности к углекислому газу описан в [9], а особенности образования и свойств гетероструктурных композиций оксидных материалов рассмотрены в работах [10-14].

Особый интерес представляет формирование литографических рисунков на традиционных подложках полупроводниковой электроники. В этом случае, например, открываются перспективы создания мультисенсорных систем с заменой теплового воздействия на канал проводимости оптическим воздействием от коллоидных квантовых точек. Также такие структуры перспективны для совмещения на кремниевой подложке чувствительных элементов со схемами обработки аналитических сигналов. Например, интеграция хеморезистивных газовых сенсоров с электронным преобразователем на одном кремниевом чипе может значительно снизить себестоимость продукции, позволит управлять сенсорным откликом и селективностью чувствительного элемента, усиливать выходной сигнал, а также передавать данные на внешние устройства посредством встроенного интерфейса [15]. Известно, что полупроводниковые оксиды металлов $\left(\mathrm{SnO}_{2}, \mathrm{ZnO}, \mathrm{In}_{2} \mathrm{O}_{3}\right.$ и др.) - это класс материалов, наиболее широко используемых для изготовления чувствительных элементов сенсоров газов [16-18]. При создании датчиков, интегрированных с полупроводниковой электроникой, возникает проблема формирования заданной топологии газочувствительного оксидного материала с развитой поверхностью на кремниевой подложке. Поэтому проблема создания литографических рисунков газочувствительных оксидов на полупроводниковых подложках представляется актуальной. 
Настоящая работа является продолжением исследований в области фрактальной литографии и представляет результаты развития разработанных методов формирования кристаллических структур с развитой поверхностью (массив проводов $\mathrm{ZnO}$ ) в локальных областях кремниевой подложки.

Цель работы состоит в развитии приемов литографии топологических рисунков со сверхразвитой поверхностью на основе проводов оксида цинка в созданных нанообластях кремниевой подложки. Экспериментально нанообласти для роста проводов $\mathrm{ZnO}$ создавались гидрофильной модификацией с помощью атомно-силовой микроскопии (локальное анодное окисление), а сами провода выращивались посредством гидротермального синтеза, позволяющего получать структуры с высокой степенью кристалличности.

На первом этапе методом локального анодного окисления формировался пространственный профиль в виде области заданной геометрии. Впоследствии на подложку со сформированным литографическим рисунком наносился зародышевый слой из наночастиц оксида цинка [19]. В рамках гидротермального метода [20,21] готовился эквимолярный раствор ацетата цинка $\left(\mathrm{Zn}\left(\mathrm{O}_{2} \mathrm{C}_{2} \mathrm{H}_{3}\right)_{2}\right)$, гексаметилтетрамина $\left(\mathrm{C}_{6} \mathrm{H}_{12} \mathrm{~N}_{4}-\right.$ уротропин $)$ и $N$-цетил- $N, N, N$-триметиламмониевого бромида (поверхностно-активное вещество). При этом ацетат цинка использовался в качестве источника ионов $\mathrm{Zn}^{2+}$, а поверхностно-активное вещество - для создания условий ограничения роста диаметра нанообъектов, формирующих нанолитографический рисунок.

В приготовленный раствор помещалась подложка со сформированным зародышевым слоем. Затем система выдерживалась в термостате при температуре $85^{\circ} \mathrm{C}$ в течение $60 \mathrm{~min}$. Реакции, протекающие в растворе, следующие:

$$
\begin{gathered}
\mathrm{C}_{6} \mathrm{H}_{12} \mathrm{~N}_{4}+6 \mathrm{H}_{2} \mathrm{O} \leftrightarrow 4 \mathrm{NH}_{3}+6 \mathrm{HCOH} \\
\mathrm{NH}_{3}+\mathrm{H}_{2} \mathrm{O} \leftrightarrow \mathrm{NH}^{4+}+\mathrm{OH}^{-} \\
\mathrm{Zn}^{2+}+2 \mathrm{OH}^{-} \leftrightarrow \mathrm{Zn}(\mathrm{OH})_{2} \\
\mathrm{Zn}(\mathrm{OH})_{2} \leftrightarrow \mathrm{ZnO}+\mathrm{H}_{2} \mathrm{O}
\end{gathered}
$$

После синтеза подложка со сформированным литографическим рисунком промывалась в дистиллированной воде.

Письма в ЖТФ, 2018, том 44, вып. 15 

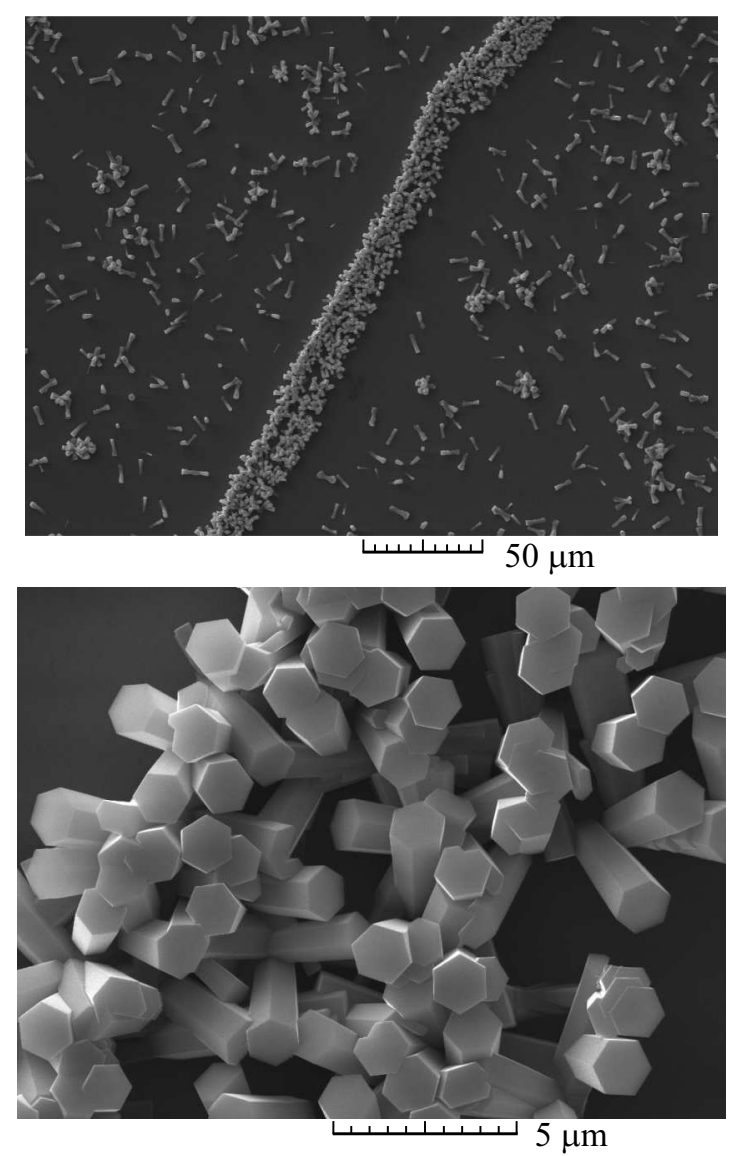

Изображения с разным увеличением литографического рисунка с кристаллической структурой со сверхразвитой поверхностью.

На рисунке представлены изображения литографического рисунка на основе проводов оксида цинка с кристаллической структурой со сверхразвитой поверхностью, сформированного в рамках заявленного способа. Анализ рисунка показывает, что преимущественный рост стержней оксида цинка происходит в области, сформированной при воздействии локального анодного окисления на подложку. Средняя

Письма в ЖТФ, 2018, том 44, вып. 15 
поверхностная плотность центров роста стрежней по данным математического анализа составила $2.25 \cdot 10^{12} \mathrm{~m}^{-2}$.

Реальная поверхность подложек в большинстве случаев неоднородна, и разные ее участки обладают различающимися каталитическими и адсорбционными свойствами. В первую очередь катализ и активированная адсорбция идут на активных центрах, в качестве которых могут выступать поверхностные атомы, испытывающие дефицит соседей. Один из способов создания центров такого рода - локальное анодное окисление с последующим вытравливанием слоя окисла. В местах формирования пространственного профиля в виде области заданной геометрии образуются атомы, испытывающие больший дефицит соседей, нежели атомы плоской поверхности. При этом в местах формирования пространственного профиля в виде области заданной геометрии появляются центры роста оксида цинка.

Таким образом, разработанные приемы представляют практический интерес для формирования мультисенсорных чипов на основе термо- и фотокаталитических, а также газочувствительных слоев.

Часть работы по исследованию зародышевого слоя для формирования литографического рисунка выполнена за счет гранта РНФ № 17-79-20239, а также стипендии Президента РФ молодым ученым и аспирантам (СП-84.2018.1).

Работа выполнялась при финансовой поддержке Министерства образования и науки РФ (проект 16.897.2017/4.6) и гранта Президента РФ для молодых кандидатов наук (МК-1882.2018.8).

\section{Список литературы}

[1] Qiang Z., Ma S.Y., Jiao H.Y., Jin W.X., Wang T.T., Jiang X.H., Zhang Z.Y. // Mater. Lett. 2016. V. 181. P. 29-33.

[2] Dimitrov D.T., Nikolaev N.K., Papazova K.I., Krasteva L.K., Pronin I.A., Averin I.A., Bojinova A.S., Georgieva A.Ts., Yakushova N.D., Peshkova T.V., Karmanov A.A., Kaneva N.V., Moshnikov V.A. // Appl. Surf. Sci. 2017. V. 392. P. $95-108$.

[3] Jiao Y., Liu Y., $Q u$ F., $W u$ X. // Cryst. Eng. Comm. 2014. V. 16. N 4. P. 575-580.

[4] Jain R., Pitchumani R. // Solar. Energy Mater. Solar. Cells. 2017. V. 172. P. 213-219.

[5] Пронин И.А., Якушова Н.Д., Димитров Д.Ц., Крастева Л.К., Папазова К.И., Карманов А.А., Аверин И.А., Георгиева А.Ц., Теруков Е.И., Мошников В.А. // Письма в ЖТФ. 2017. Т. 43. В. 18. С. 11-16.

Письма в ЖТФ, 2018, том 44, вып. 15 
[6] Uahabi K.L., Atounti M. // Ann. Univ. Craiova. Mathem. Comput. Sci. Ser. 2015. V. 42. N 1. P. 167-174.

[7] Tian Y., Garcíade Arquer F.P., Dinh C.T., Favraud G., Bonifazi M., Li J., Liu M., Zhang X., Zheng X., Kibria G., Hoogland S., Sinton D., Sargent E.H., Fratalocchi A. // Adv. Mater. 2017. V. 29. N 27. P. 1701165.

[8] Мошников В.А., Максимов А.И., Александрова О.А., Пронин И.А., Карманов А.А., Теруков Е.И., Якушова Н.Д., Аверин И.А., Бобков А.А., Пермяков Н.В. // Письма в ЖТФ. 2016. Т. 42. В. 18. С. 81-87.

[9] Karthik T.V.K., Martinez L., Agarwal V. // J. Alloys Compd. 2018. V. 731. P. 853-863.

[10] Карпова С.С., Мошников В.А., Мякин С.В., Коловангина Е.С. // ФТП. 2013. T. 47. B. 3. C. $369-372$.

[11] Бобков А.А., Лашкова Н.А., Максимов А.И., Мошников В.А., Налимова С.С. // ФТП. 2017. Т. 51. В. 1. С. 63-67.

[12] Сюлейман Ш.А., Якушова Н.Д., Пронин И.А., Канева Н.В., Божсинова А.С., Папазова К.И., Ганчева М.Н., Димитров Д.Ц., Аверин И.А., Теруков Е.И., Мошников В.А. // ЖТФ. 2017. Т. 87. В. 11. С. 1707-1711.

[13] Мошников В.А., Налимова С.С., Селезнев Б.И. // ФТП. 2014. Т. 48. В. 11. C. $1535-1539$.

[14] Spivak Yu.M., Myakin S.V., Moshnikov V.A., Panov M.F., Belorus A.O., Bobkov A.A. // J. Nanomater. 2016. V. 2016. P. 2629582.

[15] Hagleitner C., Hierlemann A., Lange D., Kummer A., Kerness N., Brand O., Baltes H. // Nature. 2001. V. 414. P. 293-296.

[16] Korotcenkov G. // Mater. Sci. Eng. B. 2007. V. 139. N 1. P. 1-23.

[17] Safonova O.V., Delabouglise G., Chenevier B., Gaskov A.M., Labeau M. // Mater. Sci. Eng. C. 2002. V. 21. N 1. P. 105-111.

[18] Pronin I.A., Averin I.A., Yakushova N.D., Dimitrov D.T., Krasteva L.K., Papazova K.I., Chanachev A.S., Bojinova A.S., Georgieva A.T., Moshnikov V.A. // Sensors Actuators. A: Physical. 2014. V. 206. P. 88-96.

[19] Бобков А.А., Максимов А.И., Мошников В.А., Сомов П.А., Теруков Е.И. // ФТП. 2015. Т. 49. В. 10. С. $1402-1406$.

[20] Wasly H.S., El-Sadek M.A., Henini M. // Appl. Phys. A. 2018. V. 124. N 1. P. 76.

[21] Кревчик В.Д., Семенов М.Б., Кревчик П.В. // Изв. вузов. Поволжский регион. Физ.-мат. науки. 2017. № 1(41). С. 92-141. 